\title{
Globalization as Boundary-Blurring: International and Local Law Firms in China's Corporate Law Market
}

Sida Liu

The worldwide expansion of international law firms has generated regulatory battles and workplace conflicts in advanced market economies as well as developing countries. This article uses the case of China to explore the changing global-local relationship in the globalization of the legal profession and to understand the role of the government in constituting the corporate law market. The author argues that the globalization of the Chinese corporate law market is a process of boundary-blurring and hybridization, by which local firms become structurally global-looking and global firms receive localized expertise. Boundary-blurring occurs in law firms' workplaces, in lawyers' career trajectories, and in state regulatory policies. It has produced a localized expertise that can be diffused conversely from local firms to global firms and has partially changed their relationship from collaboration to competition. Consequently, it becomes increasingly difficult for the government to make or enforce any substantive policy to clarify the market boundary between these two types of law firms.

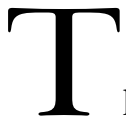

he worldwide expansion of international law firms has been one of the most remarkable developments for the legal profession in recent decades (Abel 1994). As these mega-law firms from Anglo-American countries land in the territories of Europe, Latin America, and East Asia, we have witnessed large-scale mergers with local firms and massive breakdowns of national barriers of legal practice. Not surprisingly, dominant voices within and outside of the profession have hailed the emergence of a global legal services

Financial support for this project was provided by research fellowships from the University of Chicago, the American Bar Foundation, and the Andrew W. Mellon Foundation. I would like to thank Andrew Abbott, Ellen C. Berrey, Robert Dingwall, John Hagan, Terence C. Halliday, John P. Heinz, Elizabeth Mertz, Robert L. Nelson, Randall Peerenboom, Christopher W. Schmidt, Carole Silver, and anonymous reviewers of the Law E Society Review for their comments on earlier drafts. The fieldwork benefited from the enormously helpful support from many of my alumni at Peking University School of Law and other colleagues in Beijing and Shanghai, whose names have to remain anonymous. The American Bar Foundation Research Seminar provided excellent ideas and suggestions for the revision of the article. Needless to say, I am solely responsible for all the errors and problems in the text. Please direct all correspondence to Sida Liu, Department of Sociology, The University of Chicago, 1126 E. 59th Street, Chicago, IL 60637; e-mail: sidaliu@uchicago.edu.

Law E Society Review, Volume 42, Number 4 (2008)

(C) 2008 Law and Society Association. All rights reserved. 
market. But this seemingly easy triumph of transnational law practice involves a complex process of boundary-blurring. Regulatory battles have been fought to defend the turfs of national law, and workplace conflicts have persisted in the practice of local and international law offices. These conflicts and battles find one of their most salient representations in the contemporary Chinese corporate law market.

In April 2006, the Shanghai Lawyers Association (SLA) published a news brief that blazingly condemned the illegal behavior of foreign law firms in China's corporate law market (Shanghai Lawyers Association 2006). Though presented without governmental support, this brief was widely reported in the international media and quickly generated fear and concern among foreign lawyers working in China. One commentator from Hong Kong even described it as "a brewing revolution against foreign law firms in China" (Prieur 2006:1). The revolution did not happen - to the relief of many practitioners and observers, no government action against foreign law firms followed the brief. Nevertheless, the publication of the brief and all the discussions around it strongly indicate the severe conflicts between local and foreign law firms in China.

It is the main task of this article to explore the changing globallocal relationship in the globalization of the legal profession and to understand the role of the government in constituting the corporate law market. Since 1992, the year the Chinese government formally permitted foreign law firms to establish representative offices in mainland China, more than 200 law firms have rushed into this lucrative market and set up offices in major cities such as Beijing and Shanghai. Besides a number of Hong Kong firms, the vast majority of these law firms come from the United States, Great Britain, France, Germany, Japan, Australia, and other developed countries. However, foreign law firms have been forbidden to practice Chinese law or to employ licensed Chinese lawyers. This regulatory burden on foreign law firms has generated interesting dynamics in the development of both foreign and local law firms in China, characterized by the enduring existence of a blurred boundary between them.

The dramatic incident from Shanghai raises the three central empirical questions of this article. First, during the formation of the Chinese corporate law market, why have foreign and local law firms increasingly conceived of each other as business competitors rather than collaborators? Second, why has the Chinese government, usually active in its regulatory policies, chosen to keep silent about the vehement market competition? And, finally, what are the consequences of this ongoing turf battle for the workplace practice and career patterns of individual Chinese corporate lawyers? 
To answer these questions, I have developed a sociological theory of boundary-blurring for the study of globalization of the legal profession. I argue that when formal government regulation of transnational law practice is ambiguous, the de facto market boundary between foreign and local law firms is constructed through a series of boundary-blurring processes, by which local firms become structurally global-looking and foreign firms receive localized expertise. These micro-level processes have partially changed the relationship between foreign and local firms from collaboration to competition and have resulted in their hybridization in the market. As a result, it has become increasingly difficult for the government to make or enforce any substantive policy to clarify the market boundary between the two types of law firms.

\section{Global Market Construction as Boundary-Blurring and Hybridization}

The practice of transnational corporate lawyers lies in the key theoretical juncture between the globalization of professions and the globalization of law. On the one hand, these high-status commercial lawyers, along with economists, accountants, and business consultants, are described by sociologists of professions as vanguards in the global diffusion of professional services beyond national boundaries (Abel 1994; Fourcade 2006; Dezalay \& Garth 1996, 2002a; Hanlon 1994, 1999). On the other hand, they are also perceived by sociologists of law as agents in the creation and transplantation of legal institutions from advanced market economies to developing countries (Halliday \& Osinsky 2006; Braithwaite \& Drahos 2000; Dezalay \& Garth 2002b; Halliday \& Carruthers 2007). Sharing similar educational backgrounds, economic interests, and professional values, members of this new global elite appear to be highly homogeneous and disembedded from the localities of their legal practice (Tamanaha 2001; Dingwall 1999).

A common feature of these various accounts of global market construction is their emphasis on the process of diffusion and the mechanism of isomorphism, a sociological concept originally proposed by the population ecologists (Hawley 1968, 1986; Hannan \& Freeman 1977) and made popular by the neoinstitutionalists (Meyer \& Rowan 1977; DiMaggio \& Powell 1983). Despite the perception that the global diffusion of institutions erodes the sovereign power of nation-states (Boyle \& Meyer 2002:72), nation-states are nevertheless the most important gatekeepers in the process of globalization because of their monopoly over admitting, channeling, or resisting global norms and institutions. In particular, the state's control over professional 
licensing often presents a major barrier in the constitution of the global professional services market.

When professionals and their firms are divided into two categories of global and local firms according to the practice licenses they possess, an unsettled jurisdictional area comes into being in the ecological system of professions (Abbott 1988). The dynamics of interaction in this area cannot be well characterized by the single mechanism of isomorphism; instead, it is a complex ecological process between market and politics. To fully understand the micro-level constitution of a global professional services market, therefore, we need to replace the concepts of diffusion and isomorphism with a theory of boundary-blurring and hybridization that (1) takes into account the power of the nation-state in defining the professional field; (2) captures the interaction between different firms and individual professionals in the unsettled jurisdictional area; and (3) distinguishes between the convergence of the global structure and the (re)production of the local cultural substance.

The central theoretical issue here, arguably, is how a profession's jurisdictional boundary is constituted in global market construction. In the sociology of professions, the boundary issue has traditionally been theorized as either market closure (Larson 1977; Berlant 1975; Abel 1988, 1989) or jurisdictional conflict (Abbott 1988). Despite their distinct theoretical origins and assumptions, both perspectives conceive of the production of a profession's jurisdictional boundary as a process of self-distinction, or what I call boundary-making. This tendency in emphasizing boundary-making is also found in the broader sociological literature on boundary-work (Gieryn 1983; Lamont \& Molnár 2002). Nevertheless, it is a false assumption that all social actors seek to distinguish themselves from other actors. In reality, interactions between social actors often take the form of boundary-blurring, in which one actor or both seek to mimic the other and blur the spatial or cultural boundary between them. For the construction of a global market, this process of boundaryblurring is particularly salient because, by definition, globalization implies the gradual convergence between national and transnational institutions and normative orders.

But boundary-blurring is not merely a synonym of isomorphism. In the context of globalization, isomorphism emphasizes the diffusion of new institutional models from the "core countries" of the global market to the "periphery," during which the institutional forms largely remain the same. In comparison, boundary-blurring is not about institutional diffusion, but a process of hybridization in which local actors become structurally global-looking while global actors get localized. The outcome of boundary-blurring in the global professional services market is the production of a localized expertise for the profession beneath its global outlook, which echoes the "decoupling" effect 
that the neo-institutionalists proposed a long time ago (Meyer \& Rowan 1977).

For the legal profession, localized expertise is not merely the technical knowledge of local law on the books, but an experiencebased and culturally sensitive expertise that grows from day-to-day legal practice. As much of the law and society literature shows, legal practice is full of uncertainty, inconsistency, and unintended consequences, thus in their work lawyers often emphasize insider access and local connections rather than the formal image of law (Silbey 1981; Merry 1990; Sarat \& Felstiner 1995; Ewick \& Silbey 1998). Although the work of corporate lawyers contains relatively high professional purity (Abbott 1981), experience and creativity in dealing with the economic, political, and cultural contexts in which their work is embedded is still a central component of their professionalism (Sarat \& Felstiner 1995; Mather et al. 2001; S. Liu 2006). This localized expertise cannot be easily diffused from one social context to another, but in a given locality of legal practice, it can be diffused conversely from local firms to global firms with work collaboration and personnel flow.

In the Chinese corporate law market, boundary-blurring processes occur in multiple sites, including law firms' workplaces, lawyers' career trajectories, and state regulatory policies. First, in law firms' workplaces, a series of techniques are developed to magnify their professional expertise beyond their jurisdiction in order to attract clients and expand business. As a result, the work style and service quality of both types of firms (i.e., global and local) are converging quickly, and a localized expertise is produced in the workplace of local firms. Second, for the career trajectories of individual lawyers, as localized expertise is now deemed preferable even for working in foreign law firms, the personnel flow between the two types of firms has changed from one direction to both directions, which further erodes the market boundary between them and leads to a broken career path for corporate lawyers. Finally, state regulations on foreign law offices contain a considerable amount of ambiguity regarding their practice scope, which leaves a gray area that can be manipulated by the government to adapt to changing national economic policies and political interests in different time periods. Nevertheless, the continual existence of this gray area also weakens the regulatory authority of the state and strengthens the boundary-blurring process by the market actors.

\section{Data and Method}

This article is part of a larger project on the competition and regulation of the Chinese legal services market. I started my first field 
journey in 2002 as an ethnographer working in a local corporate law firm in Beijing for six weeks (February-April 2002). In 2004, I went back to the same firm for another eight-week participantobservation (July-September 2004) and conducted 24 in-depth interviews with corporate lawyers in six local law firms. The main findings are reported in an earlier article in the Law E Society Review (S. Liu 2006). These fieldwork experiences provided me with valuable insider knowledge of Chinese corporate lawyers' work and of the complex market and political environments for their legal practice. Some of the interview data collected in 2004 are also used in this article.

The main fieldwork for the present article was conducted from July 2006 to May 2007, together with in-depth interviews on other sectors of the Chinese legal services market. The total number of interviews was 178 (in 11 provinces), in which 47 interviews were directly concerned with the relationship between foreign and local firms in the corporate law market. ${ }^{1}$ The 47 interviewees included 24 lawyers in 10 local firms, 18 lawyers in 14 foreign firms, 3 officials from the Ministry of Justice and municipal justice bureaus in Beijing and Shanghai, and 2 other informants. ${ }^{2}$ The 14 foreign firms included 8 American firms, 4 British firms, one French firm, and one Australian firm. In terms of lawyers' seniority, the 42 lawyers included 18 associates and 24 partners, of which 11 were or used to be managing partners of their firms.

The interview questions were designed as semi-structured and open-ended, and all the 47 interviews were conducted in Beijing and Shanghai, the two cities where most foreign law offices and elite local corporate law firms concentrate. My educational background from a prestigious law school in China and previous work experience in Beijing greatly facilitated the interviews. Most interviewees were very cooperative and provided frank responses regarding their practice as well as sharp opinions on the market competition and regulation. This is particularly striking for the foreign lawyers who were under pressure after the April 2006 SLA news brief. Out of the 19 lawyers in foreign firms that I contacted, only one person rejected the interview because of sensitivity.

1 The interview codes in the following text are in the form of "IN06201," in which "IN" refers to the interview, "06" is the year (e.g., 2006) the interview was conducted, "2" is the project number, and " 01 " is the number of the interview under the project.

${ }^{2}$ Note that many of my lawyer interviewees, particularly the Chinese nationals, have work experiences in both foreign and local firms, so it is not useful to sharply distinguish their current institutional affiliations. 


\section{Early Years of the Chinese Corporate Law Market}

Foreign law firms first came to China following their clients. As early as 1978-1979, shortly after the Cultural Revolution, a few American law firms already began to represent globalizing American companies in foreign investment negotiations with Chinese enterprises (IN07207). At that time, there was no concept of commercial lawyering in China, and the Chinese legal profession was only formally revived in 1980, with most lawyers doing criminal and noncommercial civil work. Until the late 1980s, all Chinese lawyers worked in "legal advisory divisions" (falü guwen chu) or state-owned law firms that were affiliated with different levels of state administrative agencies and work units (Michelson 2003). Not surprisingly, none of the foreign law firms entering China was allowed to establish a formal office - they had to do their daily work in some major hotels in Beijing and Shanghai (IN07201; IN07207). Foreign lawyers retained by government agencies or work units were called "legal expert" instead of "legal counsel" (Ministry of Justice, State Bureau of Foreign Experts, and Ministry of Foreign Affairs 1981), and their number remained limited. Nevertheless, because of the nonexistence of local corporate lawyers and the urgency of attracting foreign investment, the small number of foreign lawyers played a vitally important role in the first decade of China's market reform and opening up.

For widely known political reasons, the steady flow of foreign capital to China halted suddenly in 1989. Most foreign law firms relocated their business to Hong Kong. Coincidentally, it was in the same year that Jun He, one of the first Chinese corporate law firms specializing in foreign-related work, was established in Beijing by a few Chinese lawyers with both government backgrounds and overseas training. This new type of "cooperative law firm" was created as an experimental form in the transition of Chinese law firms from state-owned firms to partnerships. The primary goal of this transition, as a founding partner of Jun He explained, was precisely to embrace the demands of incoming foreign investment, because few foreign investors would trust a state-owned law firm regarding their commercial secrets (IN04217).

The period of the early 1990s was a difficult time for the newly born Chinese corporate law firms. By 1992, on the eve before partnership was permitted, the Beijing Bureau of Justice (BOJ) had only certified 10 cooperative law firms. These Chinese firms rarely had any foreign clients, and their primary business was to represent state-owned Chinese enterprises to deal with foreign investors in joint ventures (IN06233). The firms did everything 
they could to survive, sometimes even having to combine high-end corporate transactions with obscure tasks such as visa work and adoption (IN07201). This difficult situation continued to 1994-1995, when most of these firms were reorganized into partnerships as a way to signal their separation from the state.

In the meantime, soon after Deng Xiaoping's southern tour in 1992, the Ministry of Justice (MOJ) made the Interim Regulation on the Establishment of Foreign Law Offices in China (hereinafter the "1992 Interim Regulation") with the State Administration of Industry and Commerce (SAIC) and began an experiment of permitting foreign and Hong Kong law firms to establish offices in mainland China. According to a former partner of Coudert Brothers, one of the first foreign law firms entering the Chinese market, the final version of the 1992 Interim Regulation was revised by their staff (IN07207). In December 1992, the MOJ certified 12 foreign law firms (including eight Hong Kong firms) to set up offices in Beijing, Shanghai, and Guangzhou. As Table 1 shows, by 1995, the number of foreign law offices had increased to 32 (including 11 Hong Kong firms).

The reappearance of foreign capital and foreign law firms in China turned out to be a big blessing for the development of local corporate law firms. According to Article 16 of the 1992 Interim Regulation, foreign law offices in China were not permitted to "represent Chinese legal affairs," to "interpret Chinese law," or to "employ Chinese lawyers." Hence, when a legal project needed formal legal opinions or court representation, the foreign firm had no choice but to collaborate with a local law firm. Almost none of the local firms, however, had adequate expertise in corporate projects such as foreign direct investments (FDIs) or mergers and acquisitions (M\&As) at that time. Consequently, foreign law firms often chose to draft the entire legal opinions by themselves and

Table 1. Growth of Foreign and Hong Kong Law Offices in Mainland China

\begin{tabular}{lcccrrrr}
\hline & 1992 & 1993 & 1995 & 2002 & 2003 & 2004 & 2006 \\
\hline United States & 1 & 3 & 6 & 33 & 43 & 42 & 57 \\
United Kingdom & 2 & 3 & 4 & 19 & 23 & 23 & 22 \\
Canada & - & - & 1 & 3 & 3 & 2 & 1 \\
Australia & - & - & - & 6 & 6 & 7 & 8 \\
France & 1 & 2 & 3 & 6 & 8 & 8 & 10 \\
Germany & - & - & 2 & 9 & 7 & 7 & 7 \\
Japan & - & - & 2 & 9 & 10 & 10 & 17 \\
Singapore & - & - & 2 & 5 & 6 & 6 & 9 \\
Others & - & - & 1 & 6 & 9 & 9 & 18 \\
Total (Foreign) & $\mathbf{4}$ & $\mathbf{8}$ & $\mathbf{2 1}$ & $\mathbf{9 6}$ & $\mathbf{1 1 5}$ & $\mathbf{1 1 4}$ & $\mathbf{1 4 9}$ \\
Hong Kong & 8 & 8 & 11 & 37 & 35 & 35 & $\mathbf{5 4}$ \\
Total (Foreign \& Hong Kong) & $\mathbf{1 2}$ & $\mathbf{1 6}$ & $\mathbf{3 2}$ & $\mathbf{1 3 3}$ & $\mathbf{1 5 0}$ & $\mathbf{1 4 9}$ & $\mathbf{2 0 3}$ \\
\hline
\end{tabular}

Notes: Data compiled from the Ministry of Justice's Public Announcements and Notices, No. 487 (1992), No. 088 (1993), February 23 (1995), No. 10-11 (2002), No. 19-20 (2003), No. 35-36 (2004), No. 57-58 (2006). 
then merely let their Chinese collaborators sign the documents (IN07208). In other words, the Chinese firms were used as "rubber stamps" that did little work but assumed all the responsibilities and risks associated with the legal documents. Although the amount of billings that foreign firms transferred to their rubber-stamp local firms was quite modest, usually a few thousand dollars and sometimes as low as $\$ 500$ (IN07201), it was the first barrel of gold for many Chinese corporate law firms.

As the Chinese economy boomed in the 1990s, the corporate law market was developing at a stunning speed. From 1990 to 2000 , China drew in more than $\$ 300$ billion in utilized FDIs and made a few hundred thousand joint ventures (Huang 2005; Gallagher 2005; IN06214), which generated abundant business opportunities for both foreign and local law firms. Besides FDI and M\&A deals, initial public offerings (IPOs) became another major type of business for the corporate law firms, with local stock markets opening up and large Chinese state-owned enterprises and banks starting to be listed abroad. Furthermore, the burgeoning real estate market in major Chinese cities also began to attract a large amount of foreign capital. Accordingly, a few leading Chinese law firms became relatively specialized in their practice, focusing exclusively on high-end corporate work such as FDIs, IPOs, real estate, or financial projects (IN06233).

By the late 1990s, both the structure and personnel of local corporate law firms had changed dramatically. All the major firms in Beijing and Shanghai had been reorganized into partnerships, and some Chinese lawyers trained and worked abroad came back and became partners in leading local firms (IN04207; IN06219; IN07208). These partners were generally fluent in English, and they brought back valuable experiences in complex corporate transactions. This significantly increased the expertise of local law firms in foreign-related projects (IN04217; IN06206). Accordingly, some leading firms refused to be the rubber stamps of their foreign collaborators anymore - they started to assume a substantive part of corporate legal projects, conducting due diligence, drafting legal opinions, etc. And some foreign firms also preferred to outsource some of their low-end work to local firms to reduce costs and minimize risks.

Therefore, by the turn of the century, the collaboration between local and foreign law firms had become more substantive and interdependent. A good symbiotic relationship was formed in this gray area of legal practice. However, the peaceful situation did not last long-China's entry into the WTO in 2001 accelerated the globalization of the legal services market and the entrance of foreign law firms (see Table 1). By early 2007, 169 foreign law firms and 72 Hong Kong law firms had been permitted to practice in 
mainland China (A. Liu 2007:3). In Beijing alone, there were 90 foreign law offices with 603 employees in January 2007. ${ }^{3}$ This rapid development has fundamentally broken the balance of competition in the Chinese corporate law market.

While foreign law firms were rushing into the Chinese market, in 2001 the State Council promulgated the Administrative Regulation on the Representative Offices of Foreign Law Firms (hereinafter the "2001 Regulation"), which ironically forbids foreign law offices to engage in "Chinese legal affairs" but at the same time permits them to "provide information concerning the impact of China's legal environment" (Article 15). In recent years, the 2001 Regulation has generated endless debates and conflicts among practitioners on both sides of the blurred jurisdictional boundary. The following discussion, therefore, focuses on the dynamics of boundary-blurring in the corporate law market since China's WTO entry and the 2001 Regulation, starting from the workplace and then proceeding to personnel flow and state regulation.

\section{The Gray Area of Practicing Chinese Law}

The conflict between foreign and local law firms in the workplace focuses on the issue of practicing Chinese law. While both the 1992 Interim Regulation and the 2001 Regulation explicitly leave a gray area for the foreign firms, to what extent they can go into or even beyond this area in actual legal practice is still an empirical question. In their work, foreign firms have adopted four different strategies: (1) compliance: providing no service related to Chinese law; (2) competition: providing services of Chinese law but not collaborating with local firms; (3) symbolic collaboration: providing services of Chinese law and only using small local firms as rubber stamps; and (4) substantive collaboration: providing services of Chinese law and collaborating with major local firms.

The choices that firms make among these four strategies first depend on their areas of practice. In IPO projects, for example, there is a clear division of labor with regard to jurisdictionforeign firms only provide services concerning Hong Kong law or New York law according to the place of listing, while the preceding reorganization part of the deal, which involves almost exclusively Chinese law, is conducted by Chinese firms (IN04203; IN06204; IN06206; IN07203). Although foreign and local firms often exchange comments regarding the legal documents, there is rarely

3 Data from the online database of the Beijing BOJ, http://www.bjsf.gov.cn/zwgk/xzgg/ P020070118395117192667.doc. 
any jurisdictional conflict between them. The compliance rate is the highest in this area of practice.

By contrast, in FDI and M\&A projects, the workplace boundaries between the two types of firms are more complex and ambiguous. By definition, FDIs and M\&As are inbound transactions within mainland China and are mainly concerned with Chinese law. A distinctive feature of this type of project is that sometimes no formal legal opinion is required in providing the services; instead, lawyers only need to do due diligence and contract negotiation, and then write memos for the clients (IN06210; IN07207). In this case, foreign firms would face a choice between competition and collaboration, i.e., they could either handle the entire project by themselves or subcontract some work to a local firm.

But what then determines the different choices of foreign firms in similar types of projects such as FDIs or M\&As? My interviews suggest that the crucial factor is financial cost-whereas top-tier firms with higher billing rates tend to outsource the low-end work (e.g., due diligence) to local firms and focus on the high-end structuring designs of the project, lower-tier firms, especially newcomers that entered the Chinese market in recent years, are much more likely to handle most of the work by themselves. ${ }^{4}$ Compare the following four comments from lawyers working in different types of firms:

We have lots of collaborations with local firms. For example, much due diligence work needs to be done by local firms, including issues of facts, property, etc. Of course, when doing it we restrict the scope and direct their work. ... Sometimes the client would consider the issue of cost. The billing rates of local firms are lower. But the work we do is of different levels, and the level of local firms is lower. ... Our work is basically on big strategic issues, such as designing the investment structure, which most local firms are not capable [of] (lawyer from a premier French firm, IN06212, Beijing).

Firms like ours certainly have collaborations with all famous local firms. Generally speaking, if a local firm is involved, we would not do the due diligence. Although we also send some people there, they [local lawyers] would write the due diligence report. Of course we would draft the final legal document, but some of our partners are not willing to do due diligence, because it takes a long time. We are particularly not willing to do it when the project

${ }^{4}$ For the classification of law firm tiers, I basically follow the 2006 issue of The Lawyer Global 100, published in association with The American Lawyer (http://www.thelawyer.com/ global100/). Among the top 100 firms, 1-25 is classified as "top-tier," 26-50 as "secondtier," 51-75 as "third-tier," and 76-100 as "fourth-tier." As European and Asian firms are underrepresented in this ranking system, when describing these firms I rely on my interviewees' evaluation rather than the tier system. 
has a restriction on the lawyer fee. Also, when it requires a legal opinion, we would also go to a local firm (lawyer from a top-tier British firm, IN07204, Beijing).

We have local agents to handle filings, but we usually do not collaborate with local law firms, excepting for some technical matters in real estate projects or for evaluating litigation. We use filing companies. The reason is that the cost structure is much better than hiring local law firms. Local law firms cost much more (lawyer from a third-tier American firm, IN06232, Shanghai).

We always do our own business by ourselves, never collaborating with Chinese firms, because FDI is mainly about negotiation, writing contract, and writing memos, not about [legal] opinions. ... In IPO projects collaboration with Chinese firms is required, but not for FDIs. The boundary between Chinese firms and foreign firms will gradually become blurred (lawyer from a second-tier British firm, IN07207, Beijing).

It is clear from these quotes that top-tier foreign firms are more willing to outsource their work because their high billing rates (usually above $\$ 500 /$ hour) make due diligence and other low-end work unpalatable, and sometimes their clients would also prefer to use local firms to reduce costs. ${ }^{5}$ On the other hand, for second-tier or third-tier firms whose hourly rates (\$300-400/hour) are not much higher than the rates of local firms (\$200-350/hour), subcontracting the work is economically undesirable. Another common concern among these firms is that local firms would steal their clients afterward - in other words, they perceive Chinese firms as their business competitors rather than collaborators (ININ06204; IN06206; IN07208). The managing partner of an American law office in Shanghai elaborated on this issue:

We didn't want to outsource our work to local law firms, because from 2001-2002, local firms became competitors. Before that they were not a threat to the practice of foreign firms, but with a lot of lawyers going back from abroad and from foreign firms, they've had the capability to produce high-quality legal documents. So collaboration between us and local firms is very difficult, because we would not outsource our business to a competitor. Otherwise they would take our clients (IN06231).

In fact, this concern of losing clients to local firms is shared by most foreign firms practicing in China. Even the most prestigious firms tightly control the work process when they outsource work to local firms by making client information anonymous, closely coordinating work procedures, or keeping the more sophisticated part of the work for themselves (IN06209; IN06212; IN06217). And some

${ }^{5}$ Needless to say, this is a general statement that has its exceptions. For instance, a distinguished Chicago-based American firm is identified by several interviewees as famous for not subcontracting its work to local firms (IN06209; IN06233). 
firms avoid collaborating with major local firms altogether-they prefer to use smaller firms or the so-called puppet firms (IN06218; IN06219; IN06233; IN07201; IN07210). These puppet firms often merely sign the legal opinions prepared by foreign firms and deal with issues of government inspection without doing much substantive legal work. Some of them were even established or directly controlled by foreign firms or foreign investors (IN06209; IN07201; IN07210). Not surprisingly, the existence of puppet firms generates a great deal of condemnation from major local law firms. A senior partner from a leading local firm in Beijing explains the situation:

Originally they [foreign firms] just threw a piece of bone for you to chew-you could not eat up the big meat anyway. Then they are afraid that the clients would become so comfortable in cooperating with us, so they go to the small firms, give you the biggest risks, but limited revenue. This is a poison for Chinese firms, a fatal lure. It appears easy, but in fact they just complete deals with many ambiguous issues under Chinese law left unresolved. When something happens, they would say, "The Chinese lawyer said there was no problem." Although Chinese law is a gray area, as long as they have the opinions of Chinese lawyers, they can totally avoid their responsibilities.... The behavior of not using major Chinese firms is very narrow-minded, for although you can avoid your risks, you cannot avoid the risks of the project. ... Every foreign firm must make a balance between project interests and maintaining clients (IN07208).

Many partners in local firms are frustrated by the frequent collaborations between foreign firms and puppet firms, yet they have little capacity to change the status quo. One fundamental reason is that, even today, foreign investors generally do not trust Chinese law firms when seeking legal services. This is particularly true for companies new to China - for them the comfort level in using a foreign firm is much higher than in using a local firm (IN06231; IN07202). Although a few leading local firms have accumulated a certain reputation and trust from foreign clients over the years (IN06206; IN06219), in general it is still difficult for any local firm to get abundant foreign business without the referral of foreign firms. In other words, their transformation from collaborators with to competitors of foreign law firms is far from complete.

Besides their reluctance in collaborating with local firms, some foreign firms also actively expand their practice scope. Despite the common understanding that litigation work is beyond the gray area, in practice many foreign firms still seek to closely control the litigation process by participating in file preparation and the design of courtroom strategies (IN06207; IN06212; IN06214). The problem is even trickier in commercial arbitration. The MOJ's 
interpretive regulation on the 2001 Regulation defines representation in arbitration as a type of "Chinese legal affair" (Ministry of Justice 2002: Article 32), which has generated many protests by foreign lawyers because representation in commercial arbitration usually does not require any professional license (IN06214; IN06217; IN06230). Although the MOJ never actively implemented the restriction, in 2005, right before Coudert Brothers dissolved globally, the firm's managing partner in Beijing and his assistant were sanctioned by the Beijing BOJ for representing clients in an arbitration case (Beijing Bureau of Justice 2005). The sanction had little actual effect after the firm's dissolution, but it suggests that arbitration is still considered by the government to be a sensitive area of practice.

To summarize, I have examined in this section how the gray area of practicing Chinese law has influenced the dynamics of competition and collaboration between foreign and local firms. The various strategies that foreign firms have adopted in their projects are not only passive adaptations to the ambiguous prescriptions in the law, but also an aggressive force that contests the blurred boundary. Local firms, on the other hand, have few stakes in constituting the gray area because of their inferior market positions. Yet their hope lies in the increasing localized expertise of working on corporate legal projects in China, which, as the next section will demonstrate, have become a vitally important element for success in this market.

\section{Boundary-Work and the Production of Localized Expertise}

The blurred boundary between foreign and local law firms is produced not only in their competition and collaboration at the firm level, but also in the day-to-day work of individual lawyers. When asked about their impression of the work style of lawyers in local firms, lawyers in foreign firms often display a sense of superiority. For many of them, particularly those who came to China in recent years, Chinese lawyers in local firms are not professional enough and sometimes lack creative thinking (IN04207; IN06208; IN06213; IN06217). For example, a lawyer who worked in California for many years and recently came back to China to manage an American law office in Beijing describes his impression of local lawyers:

When I work with local firms I always feel they are in the secondary position, often not proactive enough and only work passively. Also, they still have some gaps in the experience of international transactions, not standard enough. Sometimes they are obsessed with some minor issues, argue harshly on some 
purely legal problems, but overlook the interest of the client. They don't know what the client wants, no creative thinking, because the lawyer's job is not just to interpret the law, but to solve business problems for the client (IN06213).

Interestingly, this complaint about the professional expertise of local lawyers was rarely heard for respondents who have practiced in China for a relatively long time. Although these lawyers also indicate some frustrations in dealing with local firms, they usually attribute the problem to the legal environment in which their Chinese colleagues are embedded. As one lawyer comments, "Chinese law is not complicated, but the 'conditions' of Chinese law are extremely complicated" (IN06203). The complexity lies in both client types and the workings of the Chinese government. On the one hand, client types in elite Chinese law firms are more diversified than those of foreign law offices: they include foreign investors, large state-owned enterprises, and private enterprises, so lawyers must use distinct strategies to accommodate different client demands (S. Liu 2006). On the other hand, Chinese corporate lawyers constantly deal with government agencies in their work, and the logic of bureaucracy makes many things unpredictable. An associate working in a large local firm in Beijing provides a very good example:

I often go to a few government agencies, mainly the CSRC [China Securities Regulatory Commission], the MOFCOM [Ministry of Commerce], the SDRC [State Development and Reform Commission], and the SASAC [State-owned Assets Supervision and Administration Commission]. For example, that M\&A Regulation by the MOFCOM, I did the first approval after it was implemented. ... Part of the deal was in Hubei Province, and one agency there had not approved it until the MOFCOM's system was closed on September 7 th. Then I went to the MOFCOM at 8 a.m. in the morning of the 8th to wait at the door of their division chief. But they said," "We have some activity at 8 a.m., you come back at 10:30 a.m." I came back at 10:30 a.m. and [they] said, "Our 8 a.m. activity was moved to 10:30 a.m., so you come back in the afternoon." Then I had to go there again in the afternoon and got the thing done (IN06216).

More than one interviewee emphasizes the lack of schedule in Chinese government agencies, which leads to the lack of predictability in lawyers' own work style (IN06216; IN06222). In other words, the work of local lawyers appears less "standard" or "professional" in the Western sense precisely because they have to adapt to Chinese social and political contexts to a deeper degree than their colleagues in foreign law offices. Sometimes this adaptation also requires creativity. A partner in a top-tier American firm 
explains how his project collaborator, a prominent security lawyer in China, uses a "Chinese" way to handle a problem:

The work style of Chinese lawyers is not the same as ours. They must adapt very often and cannot make a rigid application of Chinese law. The most important thing about being a lawyer in China is not legal codes, but creativity. ... I will give you an example. When a large state-owned bank was to be listed [in the stock exchange], it had to be separated into two companies. But according to the Corporation Law, the two companies must assume mutual responsibilities, so the listed company has to assume responsibilities for those credit unions that do not make money. At that time my collaborator thought of an idea. He found an interpretation of the Contract Law, which was in conflict with the Corporation Law, but he argued that Contract Law and Corporation Law were at the same level, so we could follow the Contract Law. But for some other issues we also followed the Corporation Law. This actually has a problem, but to list the company we had no other choice. For this issue we asked many people. Of course the best would be for the NPC [National People's Congress] to make a legislative interpretation, but the NPC could not do it in time. Then we contacted the Supreme [People's] Court, still could not do it. Finally we organized a symposium of legal experts through the Ministry of Finance and produced a symposium memo, so that it could become a legal basis in case there would be a problem later. Things like that American lawyers cannot do, but this is not to say my collaborator is a bad lawyer when he did it. In fact, it shows he is a very good lawyer (IN06206).

This example is in sharp contrast to the earlier comment made by a less experienced foreign lawyer, that Chinese lawyers lack creative thinking. What we see here is a distinctive type of professional expertise that fits the Chinese context well and also meets the goal of the client. Because listing the state-owned bank in the stock exchange was an important part of national economic policy, the lawyer tried to mobilize several central state agencies to fix the legal obstacle and eventually made the deal. It may seem an odd solution to an American corporate lawyer, but this is precisely how professional expertise works in the social context of China, where government agencies still control much of the national economy. It is a perfect example of the localized expertise that Chinese corporate lawyers have developed in their day-to-day legal practice.

The possession of localized expertise does not make local firms content with their practice. Instead, almost all leading local firms in Beijing and Shanghai actively seek to imitate the business model of foreign firms. From minor issues such as document settings and Web site design to more substantive aspects such as billing method 
and management structure, these Chinese law firms want to look similar to the Anglo-American mega-law firms in almost every way, even firm size. In the past few years, all the large Beijing law firms have grown substantially: the biggest firm, King \& Wood (Jin Du), has more than 600 lawyers in 11 offices, including overseas offices in Hong Kong, Tokyo, and the Silicon Valley. Even some partners in foreign law offices agree that Chinese firms are quickly catching up, though they still have reservations about the substantive effect that these formal changes would generate (IN06230; IN07207).

Indeed, although the outlook of local firms has changed dramatically over the years, their work style has largely remained the same. Business referrals and cooperation among partners are not common, and the majority of projects are still carried out by partner teams rather than project teams (S. Liu 2006). In other words, the growth in firm size has not brought about any fundamental change in the ways that the legal work is conducted. This decoupling between formal structure and work is particularly salient in the way legal work is organized and conducted, as an experienced managing partner of an American firm describes:

Chinese law firms are not operating as firms, but as individual partners. Just like a boutique. This would generate big problems when the transaction involves multiple offices. Even if a Chinese firm has offices in both Beijing and Shanghai, one partner would never give the business to another partner, especially in a different city. They cannot divide the money. This is not the case for us - we always put the client's needs as our first priority, and we trust the work quality of every office. If the partners in one office were not trustworthy, then that office would be closed down (IN06217).

The lack of cooperation among partners leads to a distinctive way of training associates. As many partners in these Chinese firms began their practice during the economic boom of the 1990s, they were able to make partner and get rich in a relatively short time, often without solid professional training. And in their work they rarely use associates outside their own partner teams. Accordingly, when training their associates, they also tend to expose the associates to clients and government agencies at an early stage. This is in sharp contrast to the training method of foreign law firms, where associates focus on legal research for several years before meeting clients (IN04207).

Many interviewees, particularly associates and junior partners in local firms, indicate that the production of their legal documents is often not as careful and fully inspected as in foreign firms (IN06205; IN06222; IN06229; IN07204). For instance, in foreign firms, memos and documents to clients usually need several 
rounds of inspection, from the legal assistant all the way to the managing partner, sometimes even requiring the revision of professional translators (IN06229). In local firms, by contrast, it is not uncommon for an associate to send a memo directly to the client without any inspection by the partner (IN06204), because Chinese clients usually do not have highly professionalized inhouse counsel to evaluate lawyers' work as foreign clients do. And almost no Chinese client would take legal action against the law firm in case of negligence (IN06203; IN06204). Besides legal research, associates in local firms also frequently attend conference calls, meet clients, and deal with government agencies in their work. The on-site training they receive in the workplace is far more complicated than the pure legal training the senior partner refers to in the previous quote.

Paradoxically, this seemingly "unprofessional" way of training associates is crucial for the production of localized expertise in the Chinese context. Precisely because associates in local firms are exposed to clients and government agencies at an earlier stage of their career than associates in foreign firms, their experiences in the Chinese legal environment also help them mature in the firm much earlier. For example, a fifth-year associate in a prestigious Chinese firm who will become partner in a few months describes his work as the following:

I improve much faster than those people in foreign firms. They basically still do due diligence and write memos every day, but I can already handle projects independently. We have a girl just coming back from a French firm, and she doesn't even dare to write a document. She told me in her firm only Of Counsel could write that kind of document. Now I handle more than 10 projects at the same time. I almost do not do due diligence anymore. I thought about it the other day, perhaps haven't done any in two years. I like meetings, business trips, attending wine parties, dealing with people. They say I'm an air-flying man in the firm, travelling all around. Actually I can improve faster this way, because the people I'm in touch with are all high-level managers in companies, investment banks, and counsel from foreign firms. I can learn a lot from them (IN06203).

This way of life is hard for a fifth-year associate in a foreign law office to imagine. Most of them are still buried in the routine legal research and due diligence work at this stage of their career. Furthermore, as most foreign firms offer no partnership track to their Chinese associates, they often pay little attention to nurturing their other professional skills besides pure legal research and English (IN06212; IN06226). Therefore, although many partners in foreign firms look down upon the quality of legal training in Chinese firms, their own training system is not perfect either-it is not 
well-directed to the complex legal environment in China and is thus disadvantageous in producing localized expertise in comparison to the training system in Chinese firms. In recent years, some foreign firms have begun to adapt to this problem by employing more Chinese lawyers and branding the expertise in Chinese law to their clients. A third-year associate who moved from a large local firm to an American law office in Beijing gives an example:

I think sometimes our firm is doing too much. We tell our clients all our people are Chinese lawyers, not even claiming we're an international firm, but emphasizing the strength of our local practice. This is very strange. It was not like this before. I guess perhaps it is because nowadays clients understand our business better, and they know foreigners indeed do not know Chinese law. Only Chinese lawyers could work. Another reason is whether our counterpart would accept. For example, in a project the client first went to a large American firm, but the counterpart refused to cooperate with it, saying that we could not communicate with those American lawyers, and we would quit the deal if you still use American lawyers. Then [the client] came to us, the counterpart first saw us as another American firm, but then discovered that we're all Chinese and we had good communication, so the deal was made (IN06222).

Arguably, branding the foreign firm as qualified in Chinese law and staffed with Chinese lawyers significantly blurs the workplace boundary between foreign and local firms. Therefore, although boundary-making exists in foreign and local lawyers' talk of each other, it is boundary-blurring that prevails in their workplaces. Moreover, beneath the firms' converging outlook, a localized expertise has grown from the workplace of local firms and has then been diffused to foreign firms with personnel flow. As the next section demonstrates, this recent trend of employing Chinese lawyers and branding localized expertise has profoundly changed the personnel and practice of both foreign and local firms.

\section{Personnel Flow and the Diffusion of Localized Expertise}

Foreign law firms' massive employment of Chinese lawyers is a relatively recent phenomenon. Before China's WTO entry in 2001, few foreign law offices in mainland China would recruit lawyers from local firms. Instead, they preferred to use either recent graduates of elite Chinese law schools or lawyers with a law degree and practice experience abroad (IN06214; IN06217). This is consistent with a traditional model of expansion identified by observers of international law firms elsewhere (Flood 1996; Silver 2002, 2007). The formal government restriction on employing 
licensed Chinese lawyers presented no de facto barrier in practice, because the lawyers being employed could simply return their People's Republic of China (PRC) lawyer license to the BOJ and stop registration. ${ }^{6}$ A more important reason is that partners in foreign firms had little trust in the professional expertise or English skills of local corporate lawyers at that time. Indeed, in the 1990s few lawyers in Chinese law firms could speak good English or write high-quality legal documents, because they merely assumed a complementary role in the collaboration with foreign firms. As a senior partner who has worked in both foreign and local firms since the 1990 s vividly comments:

Let me make an analogy. Most Chinese lawyers are scholars of literature, but not writers. But foreign lawyers are both scholars and writers. What's the meaning? Usually foreign lawyers write legal documents, and Chinese lawyers make comments. But people who make comments cannot write literature themselves (IN04207).

While foreign firms had no intention to employ local lawyers, local firms were desperate to attract talent from both foreign firms and abroad ever since the mid-1990s. And their efforts have gradually paid off over the years. For example, in Jun He, almost half of the partners have years of education and work experience in the United States, Great Britain, or other developed countries, and about 70 percent of their associates above third-year have at least a foreign law degree (IN04217; IN06233). The makeup of the personnel in King \& Wood, Zhong Lun, or other leading local firms is similar (IN04222; IN06219; IN07208). Many of these lawyers worked in the China offices of foreign law firms as associates and then returned to local firms because foreign firms offered no partnership track (IN06226; IN06232). In other words, in the first decade (1992-2001) of the coexistence of foreign and local law firms, the personnel flow was basically one-directional, i.e., only senior associates returned from foreign firms to local firms and became partners, but not vice versa.

From 2001 to 2007, more than 100 new foreign and Hong Kong law offices were set up in Beijing and Shanghai (Table 1). This not only increases the competition for legal projects among the firms, but also greatly intensifies their competition for legal talent. While newcomers were busy setting up their offices, the total number of lawyers in many existing foreign law offices also doubled or even tripled in less than five years (IN06225). Where did all these foreign firms find so many qualified lawyers in such a short

${ }^{6}$ In China, there is a distinction between lawyers' qualification certificate (zige zheng) and practice license (zhiye zheng). When returning their practice license to the $\mathrm{BOJ}$, lawyers would not lose their qualification. 
period of time? Apparently, they had to recruit a large number of lawyers from local firms in addition to expatriates, returning Chinese nationals from overseas, and new graduates.

In the meantime, with the continual flow of personnel from foreign to local firms, the professional expertise of local lawyers has been substantially improved - they have become both "scholars" and "writers" of legal documents (IN04207; IN06217). This is not merely an appropriation of legal technologies from foreign firms, as many foreigners believe (IN06225), but the creation of a localized expertise that adapts to the unique legal environment in China. As the previous section has shown, many foreign firms recognized the importance of this localized expertise to their business and began to actively recruit experienced lawyers from local firms. One common recruiting method that foreign firms use is to find candidates through headhunting firms, and the quick expansion of foreign law offices in both Beijing and Shanghai even produced a few headhunting firms specializing in recruiting lawyers. The CEO of a Shanghai-based headhunting firm, for example, explains the criteria for selecting candidates for foreign firms:

Of all the requirements of foreign firms in recruiting Chinese lawyers, the first is good English. People with good English would have a 40-50 percent advantage. The second is good experience, in general, more than three years of experience in King \& Wood or Jun He. Then we look at law school background and the Chinese and foreign bars.... Partners in foreign firms are all foreigners, so people who have bad English would never pass the interview. Although they don't normally say this, English is certainly the primary criterion (IN06226).

This overwhelming emphasis on English use is confirmed by several senior partners in foreign firms (IN06230; IN09231; IN06232), and it even causes gender imbalance in many firms, as female lawyers usually have better language skills (IN06226). In some foreign firms, virtually everyone except for a few partners is female. Besides English, the most crucial criterion is the lawyer's practice experiences in mainland China, or the localized expertise. Ideally, all foreign firms would prefer senior associates or junior partners to junior associates, yet experienced lawyers are not easy to find. Because foreign law firms rarely offer a partnership track to their Chinese employees, few promising senior associates or junior partners in local firms would want to switch to a foreign firm. Consequently, in practice most foreign firms target local firm associates with three to five years of experience. The managing partner of a Shanghai-based American law office describes their recruitment strategy: 
Some people say now the competition for talent is very severe, but it depends on what seniority level you're talking about. For seventh-year experienced lawyers, there are very few choices. It is unrealistic for us to get them. So our strategy is to get some very smart and highly qualified junior lawyers. When recruiting lawyers, we give them an English test to see whether their English has reached a certain level. We also pay attention to their international experience, for example, whether they have a LL.M. or J.D. degree. . . But it is true that there is no hope in becoming partner in foreign law firms. It is the same thing with women and racial minority lawyers in the U.S. You're not the powerful group in the organization (IN06232).

Foreign firms' concentration on recruiting middle-level associates has caused some devastating consequences to the leading local firms. For example, the Beijing office of a leading local firm lost 27 associates in 14 months around 2005-2006, all of whom had this level of experience (IN06208; IN06211; IN06221). It significantly reduced the work quality of the firm, as a senior associate explains:

Recently our firm has been in chaos. This summer many people left, all third-year or fourth-year. Almost everybody who was capable to work left the firm, because the income in foreign firms is basically twice as much as ours. Now when lawyers in our firm chat together, we only discuss who went where. A few foreign firms stole many people from us. Our partners are also holding meetings to discuss how to solve the problem.... The impact of losing so many people is tremendous, because the newcomers could not work right away, and the partners would not interfere, so sometimes documents written by interns were directly sent out. It decreased the quality of our products, also damaged our reputation. Last year there was a client referred by a foreign firm. Just because all our capable people left, the client was very dissatisfied with the product, and they said Chinese firms were not good enough (IN06211).

Another associate in the same firm also indicates that, when these experienced associates left and were replaced by associates from other local firms, it even changed the culture in the workplaceshe did not feel the same collegiality among lawyers anymore (IN06221). And, more seriously, when partners in local firms realize that their best associates may leave the firm in a few years, they tend to invest much less in their training (IN06201).

Why would middle-level associates in local firms want to switch to a foreign firm? The obvious answer is income. Table 2 presents the results of a salary survey published by LawInn, a Shanghaibased legal consulting firm. According to the survey results, for junior associates without a foreign law degree, the average salaries in foreign and local firms are quite similar; for middle-level "legal 
Table 2. Average Annual Salaries of Associates (in RMB), 2006

\begin{tabular}{|c|c|c|c|c|c|c|}
\hline \multirow{3}{*}{$\begin{array}{l}\text { Position } \\
\text { Degree }\end{array}$} & \multicolumn{4}{|c|}{ Foreign Firms } & \multirow{2}{*}{\multicolumn{2}{|c|}{$\begin{array}{c}\text { Local Firms } \\
\text { Associate }\end{array}$}} \\
\hline & \multicolumn{2}{|c|}{ Associate } & \multicolumn{2}{|c|}{ Legal Consultant } & & \\
\hline & J.D. or LL.B. & LL.M. & LL.M. & PRC degree & LL.M. & PRC degree \\
\hline Senior $(6-10)$ & $2,025,000$ & $1,609,000$ & 614,000 & 469,000 & 346,000 & 305,000 \\
\hline Middle (3-5) & $1,215,000$ & 799,000 & 350,000 & 350,000 & 278,000 & 248,000 \\
\hline Junior (1-2) & $1,030,000$ & 604,000 & 139,000 & 121,000 & 163,000 & 119,000 \\
\hline
\end{tabular}

Notes: The survey data were published by LawInn HR Consulting Co. in 2006. The sample size is 183 lawyers working in both foreign and local law firms. In the original survey, foreign firms are divided into two groups: (A) U.S., U.K., or Australian headquartered firms with global reach and multiple locations; and (B) European and East Asian headquartered regional firms with a limited number of offices. Because (B) type firms usually do not distinguish between associates and legal consultants, in this table only the results of (A) type firms are presented. Local firms include both large generalist firms and smaller but not less prestigious boutique firms. The currency exchange rate between RMB and U.S. dollars was approximately 8:1 in 2006.

consultants" (no foreign bar), ${ }^{7}$ the average salary in foreign firms is about 1.4 times that of associates in local firms; for middle-level associates (with foreign bar), the average salary in foreign firms is more than twice that in local firms; for senior associates, the difference is even more salient. Therefore, it is very tempting for middle-level associates in local firms to go abroad to get a foreign law degree and then join a foreign firm. Or in case they do not want to study abroad, they can still directly join a foreign firm as a "legal consultant" and earn a better salary.

Besides the advantage of income, another important reason for associates to choose foreign firms is to gain a different style of legal training (IN06209; IN06217). However, several interviewees who switched from local to foreign firms all indicate that they were somewhat disappointed by the training system there (IN06215; IN06222; IN07204). Yet working in a foreign firm still can bring many other worthwhile experiences, including improving language skills, business sense, and firm management (IN06226). Nonetheless, the biggest disadvantage of working in foreign firms is the lack of partnership track. Until today, most American law offices in China would only promote expatriates or Chinese nationals with long-time overseas practice experience to partner. Without such experiences, the highest position that a home-grown Chinese associate could expect is Of Counsel, even if the associate obtained a U.S. law degree and passed the New York bar exam (IN06215; IN06226). The situation in British or European firms is

${ }^{7}$ Because of the government restriction on foreign law firms' employment of licensed Chinese lawyers, if a lawyer with the PRC license but no foreign license joins a foreign law firm, his or her title will be "PRC legal consultant" or "China advisor" instead of "associate." 
similar. As a result, when Chinese associates decide to join foreign law firms, most of them are already prepared to leave the firm in a few years - the common options include partners in local firms, in-house counsel, or simply exiting the legal profession altogether (IN06212; IN07206).

The increasingly large number of returning associates from foreign firms has also changed the promotion patterns in local firms. Because returning lawyers usually have better English and closer connections with foreign firms and foreign clients, which would generate more business opportunities for local firms specializing in foreign-related work, these firms are more inclined to make them partner rather than promoting their own associates (IN04219; IN06209). Meanwhile, some leading local firms also choose to promote their best associates in a relatively short time (e.g., five years) to prevent them from being "stolen" by foreign firms (IN06203; IN06208). But in general, in local firms there are still more "airborne" partners from foreign firms than "home-grown" partners.

Therefore, as Figure 1 demonstrates, the typical career path of young Chinese corporate lawyers becomes a broken trajectory: working in a leading local firm for three or four years, getting an LL.M. from an American or British law school, and then switching to a foreign firm, with the expectation of returning to a local firm or becoming in-house counsel in a few years. Neither foreign nor local firms can provide them a continuous and stable career trajectory. At the partner level, exchange of personnel is not as frequent as at the associate level, though in recent years a few senior partners in leading local firms with international experiences became managing partners of new foreign law offices (IN07202). This two-directional personnel flow has greatly facilitated the hybridization between local and foreign law firms, but at the same time it has made the career choices of many Chinese corporate lawyers a real dilemma.

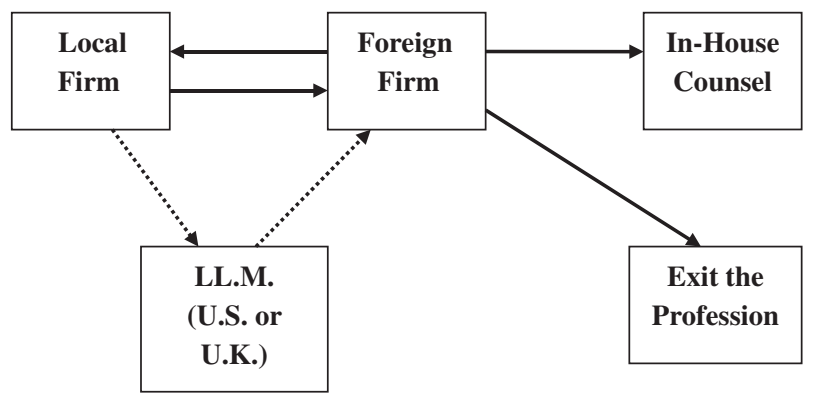

Figure 1. A Broken Career Path for Chinese Corporate Lawyers 


\section{Managing the Blurred Boundary: State Regulation of the Corporate Law Market}

Foreign firms' large-scale employment of Chinese lawyers has generated concern from both local firms and the BOJs. According to several interviewees, the 2006 SLA brief was directly triggered by the heavy loss of associates in a few major local firms in Shanghai (IN06223; IN06226; IN06227). The brief listed eight "illegal business activities" conducted by foreign law firms in China, including (1) hiring licensed Chinese lawyers; (2) drafting Chinese legal documents; (3) conducting due diligence; (4) engaging in litigation and arbitration; (5) handling registration, application, and filing with government agencies; (6) controlling Chinese law firms; (7) using misleading propaganda; and (8) avoiding Chinese taxes and foreign currency controls (Shanghai Lawyers Association 2006).

Many foreign lawyers practicing in China find these accusations difficult to accept. Although such practices do exist and, from a statutory point of view, could be interpreted as violations of the government regulation on foreign law offices, they are still in the gray area and have been tolerated by the BOJs for a long time. An experienced managing partner of an American law office in Beijing, for example, makes the following comment:

The SLA brief has eight arguments regarding the practice of foreign law firms, but some of them are very silly. For example, they say we use high wages to attract their associates, but what's wrong with that? Also, the MOJ's restriction on arbitration work has already been abolished after our protest, but they still list it as one of the problems. ... For the tax problem, I'm sure foreign law firms are generally more compliant with the PRC tax rules than Chinese law firms. As for local firms controlled by foreigners, I don't think 10-20 percent foreigners in the management committee would make a big difference. For those local firms established by foreigners, if they feel bad, then go ahead and do something about it. Those firms are not the best firms, so we don't care (IN06217).

Despite the indifferent attitudes of some foreign firm partners (IN06217; IN06231; IN07202; IN07207), the SLA brief had a real impact after it was widely reported by the foreign media in May 2006. The American Chamber of Commerce in Shanghai immediately held an emergency meeting of foreign lawyers and in-house counsel in foreign companies, and they all agreed to keep silent in front of the media and the potential BOJ investigation (IN06230; IN06232; IN06509). Some foreign firms changed the titles for their Chinese associates, some adjusted the contents of their Web sites, some added a disclaimer to all their e-mails and legal 
documents, ${ }^{8}$ and some even stopped employing new Chinese associates until it was clear that no government action would follow (IN06201; IN06202; IN06226). Even more troublesome were the rumors being circulated around the brief. A senior partner in the Shanghai office of a major American firm describes his experience at that time:

I think the SLA brief was a very unfriendly action. We were shocked when we heard the news. And we heard about it much later, about a month after it came out in April, when people told us to look at the SLA's Web site. They didn't give any notice to us, and the media played a very negative role, both domestically and internationally. I got many requests for media interviews at that time, but what can I say on an issue like this? We learned that we were still being treated as guests in China, so as guests, you must behave very carefully and friendly. We have no idea who was behind this memo, although certain lawyers and firms had more exposure in the media. There were all kinds of rumors at that time, some said it was no big deal, and others said this was the first step of a large campaign against foreign law firms. For a while we were really afraid that foreign law firms would be kicked out of China. Then nothing happened until now, but I have no idea what will happen in the future. To be honest with you, now we really have to find out who our friends are and who would throw a knife at our back. This is not to say it has become a friend-or-foe situation, but we have to be very careful about some firms (IN06230).

Apparently, the SLA brief substantially heightened the conflicts between foreign and local firms. Many lawyers, including some senior partners in local firms, expressed the concern that it might produce negative effects on their business (IN06209; IN06212; IN06227), because local firms still depend on the referral of foreign firms for a substantial proportion of their revenue. In the meantime, some lawyers also believed that the SLA brief was merely an indication that a few local firms could not bear the heated competition from foreign firms (IN06231; IN07202; IN07204). In fact, both the two main Shanghai firms behind the SLA brief experienced notable business decline and personnel loss in recent years, which, as an informant argues, was the true underlying reason for their radical action (IN06226). However, in the opinions of many foreign firm lawyers, these local firms in

${ }^{8}$ A typical disclaimer reads like this: "The advice above is based on our experience as international counsel representing clients in their business activities in China. As is the case for all international law firms licensed in China, we are authorized to provide information concerning the effect of the Chinese legal environment, however we are not permitted to engage in Chinese legal affairs in the capacity of a domestic law firm. Should the services of such a firm be required we would be glad to recommend one" (Author's field notes, 7 Nov. 2007). 
Shanghai cannot really compete with them, because they occupy completely different market niches (IN06230; IN07201).

Interestingly, leading local firms in Beijing appear to be much less radical than the Shanghai firms. Interviewees on both sides all indicate that such an incident would never happen in Beijing (e.g., IN06205; IN06206; IN06209; IN06217; IN07202). This, however, does not imply that competitive pressures from foreign firms are less severe there. As the previous section has shown, leading Beijing firms also experienced a heavy loss of associates around the same time. Nevertheless, the firm size and business diversity of these Beijing firms are very different from their Shanghai counterparts, as one partner from a leading Beijing firm explains:

For the SLA problem, the situation in Beijing is similar, but the business of Beijing firms is across the whole country, not just FDIs, but also other fields like securities and venture capitals. Local firms in Shanghai have a very narrow service range, only foreign investments around the Yangtze Delta area, so of course their relationship with foreign firms is a matter of life and death. ... Except for a few branch offices of Beijing firms, most law firms in Shanghai are small firms (IN06205).

This partner's comment is also confirmed by other interviewees, including some senior partners in Shanghai (IN06206; IN06227; IN06233). Beijing firms are less radical in their attitudes toward foreign firms because they have more collaboration with them in a variety of legal fields, including many large-scale IPO projects. In addition, the large size of leading Beijing firms also makes their business less vulnerable to competition from foreign law offices, which usually have fewer than 50 lawyers and staff.

Why are Beijing firms generally bigger, stronger, and more profitable than Shanghai firms? Some lawyers emphasize cultural or historical reasons, e.g., law firms in Shanghai had always been small boutique firms even before the PRC, and Shanghai businesspeople are more individualistic and do not share the same collegial culture as northerners (i.e., those in Beijing; IN06227; IN06233). However, more important is the ecological reason, i.e., almost all central government agencies and headquarters of large state-owned enterprises are located in Beijing, so it is much easier for Beijing firms to get access to both the largest local clients and the most important state agencies (IN06228; IN07204). In fact, many founding partners of leading Beijing firms used to work in central state agencies, and some firms even keep a number of retired officials from central agencies or relatives of high-ranking officials to facilitate exchanges with the state (IN06205; IN06227). This ecological position not only gives the Beijing firms market 
advantages over the Shanghai firms, but also provides them with better stakes in the relationship with foreign firms.

Foreign firms, however, are not totally distant from powerful central state agencies such as the MOFCOM or the SDRC. Several senior partners in foreign firms all indicate that these government agencies are becoming very sophisticated in their regulatory policies (IN06217; IN06230; IN06231). Because these policies often directly shape the flow of foreign capital, foreign firms also seek to use official channels and personal connections to influence their policymaking (IN06217). On the one hand, diplomatic agencies such as the American Chamber of Commerce provide a good platform for foreign law firms and their clients to negotiate with the Chinese government. On the other hand, many foreign firms also employ some well-connected lawyers or even a few "government specialists" to facilitate their exchange with government agencies (IN06205; IN06217).

The close connections between law firms (both foreign and local) and powerful central state agencies make the MOJ's regulation of the corporate law market particularly difficult. Although MOJ officials are well aware of the boundary-blurring behaviors of foreign firms, they also understand that the issue of regulating foreign firms is closely related to the broader commercial and foreign policies of the Chinese government as well as the interests of several other central agencies, all of which are more powerful than the MOJ (IN06215; IN06217; IN07202). As an experienced managing partner of an American firm explains:

The MOJ regulation on foreign law firms is about protectionism, which is very clear, but it is also about politics. This is not just the lobbying of local firms, but the politics within the government. The MOJ regulation is poorly implemented because if it were well implemented, then it would cause severe restriction to foreign investment. That would be very bad for the country. The MOJ is a powerless state ministry, and it has to consult with other ministries when making its policies. But if the MOJ consults the MOFCOM regarding restricting foreign law firms, the MOFCOM would certainly disagree, so the regulation could never be implemented. The regulation on foreign law firms ultimately depends on the larger business environment in China (IN06217).

A junior partner of a leading local firm who used to attend relevant meetings of the Beijing BOJ also refers to the same dilemma of the MOJ:

The MOJ's policies are always changing, which is related to the bigger environment of the whole market. Actually, whether or not to restrict foreign firms is related to the question of whether to restrict foreign capital or to encourage foreign capital. When the 
country needs foreign capital, it would be looser for them; when [the country] needs to restrict foreign capital, it would be tighter for them. This is not simply an issue of illegal or not. As you know, the MOJ is a very weak ministry among the Chinese ministries, and for issues like this, they must listen to the opinions of those agencies like the MOFCOM or the SASAC, and see what the country's broad economic policies are, so their attitude is always ambivalent, often swaying back and forth (IN06215).

What these two partners suggest is a subtle process of boundary maintenance by which the MOJ keeps the blurred boundary on purpose to leave enough flexibility for adapting to changes in the business environment and in other ministries' policies. It leads to long-term inaction regarding the corporate law market - even the vehement SLA brief did not produce any subsequent government action from the MOJ. Nevertheless, this strategy of keeping a sword of Damocles (IN07207) also significantly reduces the regulatory authority of the MOJ over the corporate law market and, as a result, most law firms pay much more attention to the policies of the MOFCOM or the SDRC than to the policies of the MOJ (IN06213; IN06218). In other words, the inaction of the MOJ further marginalizes its position in the state regulatory structure.

Besides these larger political concerns, the MOJ and the BOJs also face some procedural obstacles in regulating the corporate law market. For example, to sanction any illegal behavior of foreign law firms, the local BOJ must collect specific and conclusive evidence for individual cases (IN06509; IN07505), but no law firm would provide such evidence to the BOJ. Even those local firms that are "victims" of the competition are reluctant to issue complaint files to the government because they are afraid of damaging their relationship with foreign firms (IN06209). In other words, the collaboration between local and foreign firms becomes an important source of protection for foreign firms' aggressive behavior in the gray area of legal practice. Without solid evidence from local firms or clients, the BOJ's sword of Damocles is simply useless.

In fact, the SLA brief was also a result of this regulatory dilemma. An informant from the Shanghai Lawyers Association tells why the brief was produced and what happened afterward:

Many media reported on our April brief. Actually, regulating foreign law firms is the BOJ's job, and the lawyers association has no power on this. But because this problem had an impact on lawyers, and many lawyers expressed concerns on this, and it accumulated for a long time, so we made the report. ... But nobody makes complaints on this problem, so we do not have evidence and can only search for the illegal stuff from the foreign firms' Web sites. Honestly speaking, it is very hard to take 
evidence. ... We wrote a report to the BOJ, and they did not make any sanction mainly because there was no evidence (IN06509).

In a sense, the powerlessness of the BOJs is also an encouragement for some foreign law firms that hope to expand their business in China. In January 2007, McDermott Will \& Emery (MWE), a Chicago-based law firm with 14 offices in the United States and Europe, opened its first China office in Shanghai, which was reported in the Wall Street Journal (Koppel \& Batson 2007). The fundamental difference of this office from other foreign law offices in China is that it was established as an independent Chinese law firm, with an "exclusive strategic alliance" with MWE. This means that officially MWE cannot share the profits of this China office, but all its China projects will be exclusively conducted by this office. The two founding partners of the MWE China office used to work in Allbright, the largest Chinese law firm in Shanghai. To them, this new form of alliance is not a violation of the 2001 Regulation, but many other lawyers and MOJ officials seem to disagree (IN07202; IN07207; IN07208; IN07505). When being interviewed in March 2007, an official from the MOJ Lawyers and Notary Work Guidance Office indicates that they considered this alliance to be illegal and were making a serious investigation (IN07505). However, the MWE China office is still operating in Shanghai, and nobody can tell whether it is a Chinese or a foreign law firm.

Is the emergence of this blurred organizational form between local and foreign firms a harbinger of the further opening of the Chinese corporate law market in the near future? Nobody knows. When asked about their predictions for the future, the interviewees gave a variety of answers. Some say that large-scale reorganizations would take place if the market is opened up (e.g., IN06203; IN06210; IN06217; IN06232), yet others believe only a few major local firms would merge (e.g., IN06230; IN06231; IN07206). In fact, around the time of the WTO entry, there were already private merger negotiations between a few major foreign and local firms, but none of them worked out (IN07202; IN07203; IN07208). When the leading local law firms have expanded into mega-firms of hundreds of lawyers, their senior partners have also become more cynical in their attitudes toward merging with foreign firms (IN04216; IN04217; IN04222; IN06219; IN07208). Needless to say, their opinions have a direct influence on the MOJ's policymaking. In contrast, most associates in both local and foreign firms are very positive toward opening up the legal services market, because this would provide them a better work environment and a more stable career path (IN04203; IN06203; IN06212). Nevertheless, most interviewees agree that there will not be any 
significant change in the next five to 10 years, and the blurred boundary will continue to exist.

\section{Conclusion}

The globalization of the legal profession is a process of boundary-blurring. In the formative years of the Chinese corporate law market, the relationship between foreign and local law firms has been gradually transformed from collaboration to competition. The jurisdictional boundary between them is becoming increasingly blurred, and business competition in the market is significantly intensified. However, this transformation from collaboration to competition is far from complete. The structure of the corporate law market is still highly stratified, and the main competitors of most firms are still other firms in the same market niche. Local firms still more or less depend on foreign firms for business referrals and assume an inferior position in the market structure. Foreign firms, on the other hand, are increasingly targeting Chinese companies investing abroad rather than focusing on incoming foreign capital, although they also rely on local firms in dealing with government agencies and major local clients.

In this sense, boundary-blurring is not equal to institutional diffusion or structural isomorphism; it is rather an imperfect hybridization between the global formal structure and the local cultural substance. What is the outcome of this hybridization? It is the production of a localized expertise that is experience-based and highly adaptive to the local political and social environment in which these global-looking corporate lawyers are embedded (Silver 2007). For the Chinese case, the nature of localized expertise is not only a matter of insider status and local connections as being important everywhere (Sarat \& Felstiner 1995), but includes sophisticated techniques by which these corporate lawyers deal with the government and the large variety of clients (S. Liu 2006). The main production sites of this expertise are the local corporate law firms, where globally trained partners and their associates constantly interact with local clients and state agencies. As these lawyers start to move from local to foreign firms, they also bring their localized expertise to the service of global firms and foreign investors.

This process, if not unexpected, is intriguing to theories on the globalization of law and professions, because it suggests that the cultural substance of law and professionalism is not only decoupled from its adopted formal structure, but also diffused conversely to the global force that seeks to penetrate local barriers. After all, compared to economics or accountancy (Fourcade 2006; Hanlon 
1994), law is a much more politically and culturally sensitive professional field - it embodies both the will of a sovereign state and the cultural tradition of a people. Therefore, the construction of a global legal profession is not simply the production and exportation of a transnational legal order (Dezalay \& Garth 1996, 2002a), but also the rebirth of a localized expertise that adapts to the nature of law at the global-local boundaries in various national contexts. In this boundary-blurring process, the structural barriers of legal practice might be gradually removed, but the cultural substance of this expertise will never disappear.

\section{References}

Abbott, Andrew (1981) "Status and Status Strain in the Professions," 86 American J. of Sociology 819-35.

- (1988) The System of Professions: An Essay on the Division of Expert Labor. Chicago: Univ. of Chicago Press.

Abel, Richard L. (1988) The Legal Profession in England and Wales. Oxford, United Kingdom, and New York: Blackwell.

—_ (1989) American Lawyers. New York and Oxford, United Kingdom: Oxford Univ. Press.

_- (1994) “Transnational Law Practice,” 44 Case Western Reserve Law Rev. 737-870.

Beijing Bureau of Justice (2005) Public Announcement on the License Abolition of the Primary Representative of the Coudert Brothers Beijing Office Tao Jingzhou. 8 Oct, Beijing.

Berlant, Jeffrey L. (1975) Profession and Monopoly: A Study of Medicine in the United States and Great Britain. Berkeley: Univ. of California Press.

Boyle, Elizabeth H., \& John W. Meyer (2002) "Modern Law as a Secularized and Global Model: Implications for the Sociology of Law,” in Y. Dezalay \& B. Garth, eds., Global Prescriptions: The Production, Exportation, and Importation of a New Legal Orthodoxy. Ann Arbor: Univ. of Michigan Press.

Braithwaite, John, \& Peter Drahos (2000) Global Business Regulation. Cambridge, UK: Cambridge Univ. Press.

Dezalay, Yves, \& Bryant Garth (1996) Dealing in Virtue: International Commercial Arbitration and the Construction of a Transnational Legal Order. Chicago: Univ. of Chicago Press.

—_ - eds. (2002a) Global Prescriptions: The Production, Exportation, and Importation of a New Legal Orthodoxy. Ann Arbor: Univ. of Michigan Press.

—_ - eds. (2002b) The Internationalization of Palace Wars: Lawyers, Economists and the Transformation of Latin-American States. Chicago: Univ. of Chicago Press.

DiMaggio, Paul, \& Walter Powell (1983) "The Iron Cage Revisited: Institutional Isomorphism and Collective Rationality in Organizational Fields," 48 American Sociological Rev. 147-60.

Dingwall, Robert (1999) "Professions and Social Order in a Global Society," 9 International Rev. of Sociology 131-40.

Ewick, Patricia, \& Susan Silbey (1998) The Common Place of Law: Stories from Everyday Life. Chicago: Univ. of Chicago Press.

Flood, John (1996) "Megalawyering in the Global Order: The Cultural, Social, and Economic Transformation of Global Legal Practice," 3 International J. of the Legal Profession 169-95.

Fourcade, Marion (2006) "The Construction of a Global Profession: The Transnationalization of Economics," 112 American J. of Sociology 145-94. 
Gallagher, Mary E. (2005) Contagious Capitalism: Globalization and the Politics of Labor in China. Princeton, NJ: Princeton Univ. Press.

Gieryn, Thomas F. (1983) "Boundary-Work and the Demarcation of Science from Non-Science: Strains and Interests in Professional Ideologies of Scientists," 48 American Sociological Rev. 781-95.

Halliday, Terence C., \& Bruce G. Carruthers (2007) "The Recursivity of Law: Global Normmaking and National Lawmaking in the Globalization of Bankruptcy Regimes," 112 American J. of Sociology 1135-202.

Halliday, Terence C., \& Pavel Osinsky (2006) "Globalization of Law," 32 Annual Rev. of Sociology 19.1-19.24.

Hanlon, Gerard (1994) The Commercialisation of Accountancy: Flexible Accumulation and the Transformation of the Service Class. London: Macmillan, and New York: St. Martin's Press.

(1999) Lawyers, the State, and the Market: Professionalism Revisited. London: MacMillan Business.

Hannan, Michael T., \& John Freeman (1977) "The Population Ecology of Organizations," 82 American J. of Sociology 929-64.

Hawley, Amos (1968) "Human Ecology," in D. L. Sills, ed., International Encyclopedia of the Social Sciences. New York: Macmillan.

—_ (1986) Human Ecology: A Theoretical Essay. Chicago: Univ. of Chicago Press.

Huang, Yasheng (2005) Selling China: Foreign Direct Investment During the Reform Era. Cambridge, United Kingdom: Cambridge Univ. Press.

Koppel, Nathan, \& Andrew Batson (2007) "A U.S. Law Firm Takes a New Route Into China," The Wall Street Journal, 30 Jan., p. B1.

Lamont, Michèle, \& Virág Molnár (2002) "The Study of Boundaries in the Social Sciences," 28 Annual Rev. of Sociology 167-95.

Larson, Magali S. (1977) The Rise of Professionalism: A Sociological Analysis. Berkeley: Univ. of California Press.

Liu, Aijun (2007) "Foreign Law Firms Push Forward, Mainland and Hong Kong Cooperate to Balance," Fazhi Ribao [Legal Daily], 22 Jan., p. 3.

Liu, Sida (2006) "Client Influence and the Contingency of Professionalism: The Work of Elite Corporate Lawyers in China," 40 Law E Society Rev. 751-82.

Mather, Lynn, et al. 2001 Divorce Lawyers at Work: Varieties of Professionalism in Practice. Oxford, United Kingdom, and New York: Oxford Univ. Press.

Merry Sally, E. (1990) Getting Justice and Getting Even: Legal Consciousness among WorkingClass Americans. Chicago: Univ. of Chicago Press.

Meyer, John W., \& Brian Rowan (1977) "Institutionalized Organizations: Formal Structure as Myths and Ceremony," 83 American J. of Sociology 340-63.

Michelson, Ethan (2003) "Unhooking from the State: Chinese Lawyers in Transition," Ph.D. Dissertation, Department of Sociology, University of Chicago.

Prieur, Mia (2006) "The Shot Heard 'Round the World: A Brewing Revolution Against Foreign Law Firms in China?," China Legal Watch, 15 June. Hong Kong: CCH Hong Kong Limited.

Sarat, Austin, \& William L. F. Felstiner (1995) Divorce Lawyers and Their Clients: Power and Meaning in the Legal Process. New York: Oxford Univ. Press.

Shanghai Lawyers Association (2006) Shanghai Lawyers Association News Brief, Issue 9, 17 April.

Silbey, Susan S. (1981) “Making Sense of the Lower Courts," 6 The Justice System J. 13-27.

Silver, Carole (2002) "The Case of the Foreign Lawyer: Internationalizing the U.S. Legal Profession," 25 Fordham International Law J. 1039-84.

(2007) "Local Matters: Internationalizing Strategies for U.S. Law Firms," 14 Indiana J. of Global Legal Studies 67-93.

Tamanaha, Brian Z. (2001) A General Jurisprudence of Law and Society. New York: Oxford Univ. Press. 


\section{Statutes Cited}

Administrative Regulation on the Representative Offices of Foreign Law Firms. 22 Dec. State Council, (2001).

Interim Regulation on the Establishment of Foreign Law Offices in China. 26 May. State Administration of Industry and Commerce, and Ministry of Justice (1992).

Joint Notice on Forbidding Foreign Lawyers to Practice in China. Ministry of Justice, State Bureau of Foreign Experts, and Ministry of Foreign Affairs, Beijing (1981).

Regulation on the Implementation of the Administrative Regulation on the Representative Offices of Foreign Law Firms. Ministry of Justice, Beijing (4 July 2002).

Sida Liu is a Ph.D. candidate in sociology at the University of Chicago and a doctoral fellow at the American Bar Foundation. His research interests include law and society, the legal profession, and political sociology. He has published articles in the Law \& Society Review and Law \& Social Inquiry, as well as several leading law and social science journals in China. His book The Lost Polis: Transformation of the Legal Profession in Contemporary China (in Chinese) was published by Peking University Press in 2008. Currently, Liu is completing his Ph.D. dissertation, "The Logic of Fragmentation: An Ecological Analysis of the Chinese Legal Services Market," which analyzes the impact of China's legal reform since the late 1970s on competition and regulation of lawyers and other legal service providers in China. 